\title{
INFORMAÇÃO CONTÁBIL NAS MICRO E PEQUENAS EMPRESAS: UMA PESQUISA DE CAMPO NA CIDADE DE TANGARÁ DA SERRA - MT
}

\author{
Riky Grachecki Vilas Boas ${ }^{1}$ \\ Márcio Íris de Morais ${ }^{2}$
}

\begin{abstract}
RESUMO
O objeto deste estudo é demonstrar qual a percepção de gestores e empresários das micro e pequenas empresas de Tangará da Serra-MT, em relação ao uso da informação contábil. Partindo do pressuposto da relevância das informações contábeis à administração das empresas, as demonstrações e relatórios contábeis, evidenciariam então, sua utilização para auxilio na tomada de decisões por parte dos gestores. Foi realizado levantamento de dados por meio de questionários, tendo como amostra 240 empresas da cidade de Tangará da Serra-MT, definidas como micro e pequenas empresas de acordo com critério do SEBRAE no período de Janeiro de 2014. Com um total de 240 respostas, as análises indicaram que a maioria dos gestores e empresários, totalizando $87 \%$, afirmam que a informação contábil é importante para o suporte a gestão das empresas, apesar de $24 \%$ deles não utilizarem as demonstrações e relatórios contábeis. Verificou-se também que os relatórios ou demonstrações mais disponibilizados pela contabilidade são o Balanço Patrimonial, a Demonstração do Resultado do Exercício e a Demonstração dos Fluxos de Caixa, 44\% dos gestores, possuem dificuldade em utilizar a informação contábil. Por fim o estudo revela que $94 \%$ dos entrevistados confiam na informação contábil que recebem da contabilidade.
\end{abstract}

Palavras-chave: Micro e Pequenas Empresas; Informações Contábeis; Contabilidade

\begin{abstract}
The object of this study is to demonstrate the perception of managers and entrepreneurs of micro and small companies Tangara da Serra-MT, regarding the use of accounting information. Assuming the relevance of accounting to corporate governance information, statements and accounting reports, then, would show its use to aid in decision making by managers. Data collection was conducted through questionnaires and a sample of 240 companies in the city of Tangara da Serra-MT, defined as micro and small enterprises according to criteria SEBRAE from January 2014. With a total of 240 responses, the analysis indicated that the majority of managers and entrepreneurs, totaling $87 \%$, say that accounting information is important to support the management of the companies, although $24 \%$ of them do not use the statements and accounting reports. It was also found that the reports or statements provided by most accounts are the Balance Sheet, the Statement of Income and Statement of Cash Flows, 44\% of managers have difficulty using accounting information. Finally the study reveals that $94 \%$ of respondents trust the information they receive accounting bookkeeping.
\end{abstract}

Keywords: Micro and Small Enterprises; Accounting Information; Accounting;

\footnotetext{
${ }^{1}$ Acadêmico do curso de Ciências Contábeis da Universidade do Estado de Mato Grosso (UNEMAT), "Campus" Universitário de Tangará da Serra, rikygrachecki@hotmail.com

${ }^{2}$ Professor do curso de Ciências Contábeis da Universidade do Estado de Mato Grosso (UNEMAT), "Campus" Universitário de Tangará da Serra, Mestre em Contabilidade pela Universidade Vale do Rio dos Sinos (UNISINOS), marciomorais@unemat.br 


\section{Informação contábil nas micro e pequenas empresas: uma pesquisa de campo na cidade

\section{INTRODUÇÃO}

Oliveira, Muller e Nakamura (2000), expressam que ao longo dos anos 90 a inserção do Brasil no processo de globalização e o crescimento da competitividade, ampliaram o dinamismo da economia brasileira expondo nossas empresas a concorrência externa, fazendo com que elas busquem excelência empresarial.

"Num ambiente assim a tomada de decisão se torna imprescindível e, por conseguinte, a qualidade e o uso das informações do seu empreendimento fundamentais" (SILVA et al, 2010 , p. 2). O processo decisório é questão de pesquisa tanto para grandes quanto para pequenas empresas e requer atenção dos gestores devido à dificuldade com os problemas diários, sendo necessárias informações concretas que supram a carência de informações administrativa e financeira dos gestores (MOREIRA et al, 2013).

Segundo Fernandes, Klann e Figueredo (2011), alguns autores afirmam que a informação contábil é fundamental para o desenvolvimento das organizações e da sociedade, considerando a contabilidade como a linguagem dos negócios. E uma das preocupações das empresas no momento atual, relaciona-se à dificuldade em escolher que informações são relevantes para as decisões que surgem no dia a dia (PORTON; LONGARAY, 2006).

Moreira et al, (2013), relatam que a informação pode ser vista como um instrumento para solucionar problemas na administração, posto que diante de um cenário tão competitivo é necessário que gestores tomem decisões a todo momento. E quando essa informação for aplicada de forma eficaz pode fazer com que a empresa se destaque diante da concorrência.

Neste contexto, Stroeher e Freitas (2008) afirmam que é evidente a importância das informações contábeis para a gestão das empresas e que o empresário, na maioria dos casos não possui conhecimentos contábeis suficientes, e em consequência não conseguem avaliar os benefícios que elas podem agregar para seus negócios. Porton e Longaray (2006) salientam que quando a empresa está em busca de lucratividade, respectivamente, está à procura da eficácia do seu negócio, e neste momento, necessita ter relatórios contábeis, saber compreendê-los e interpretá-los, de modo a auxiliar na obtenção dos resultados que são almejados.

As demonstrações contábeis no Brasil para as pequenas e médias empresas devem ser elaboradas conforme determinação do Comitê de Pronunciamentos Contábeis que aprovou o Pronunciamento Técnico PME - Contabilidade para Pequenas e Médias Empresas, elaborado através do The International Financial Reporting Standard for Small and Medium-sized Entities 


\section{Informação contábil nas micro e pequenas empresas: uma pesquisa de campo na cidade de Tangará da Serra - MT \\ Riky Grachecki Vilas Boas; Márcio Íris de Morais}

(IFRS for SMES). O Pronunciamento Técnico PME foi aprovado pelo CFC através da Resolução ${ }^{\circ}$ 1.255/09 que estabeleceu a NBC T 19.41, determinando então que esta norma fosse designada à utilização por pequenas e médias empresas (MORAIS, 2012).

O Serviço Brasileiro de Apoio às Micro e Pequenas Empresas (SEBRAE) utiliza para fins de estudos sobre empresas um critério para caracterizá-las por porte. Assim, classificamse de acordo com o número de pessoas ocupadas nas organizações: microempresa até 9 pessoas ocupadas; pequena empresa de 10 a 49 pessoas ocupadas; média empresa de 50 a 99 pessoas ocupadas; e grande empresa acima de 100 pessoas ocupadas (SEBRAE, 2005).

Diante desse cenário surge a seguinte questão problema: Qual a percepção de gestores e empresários das micro e pequenas empresas de Tangará da Serra-MT, em relação ao uso da informação contábil?

Esta pesquisa tem como objetivo geral investigar a percepção de gestores e empresários das micro e pequenas empresas de Tangará da Serra-MT em relação ao uso da informação contábil. Como objetivos específicos pretende-se: caracterizar as microempresas e empresas de pequeno porte na cidade de Tangará da Serra, Mato Grosso; avaliar a importância que é dada pelos gestores e empresários a relatórios recebidos da contabilidade e; verificar a confiabilidade das informações contábeis, emitidas pelos gestores e empresários.

\section{REFERENCIAL TEÓRICO}

Nesta seção é descrito a importância e a representatividade das micro e pequenas empresas para a economia. Posteriormente é relatado sobre gestão empresarial, abordando um pouco sobre a informação contábil como auxílio para a gestão das empresas. Por fim é abordado sobre as demonstrações contábeis para pequenas e médias empresas.

\subsection{A representatividade e importância das micro e pequenas empresas para a economia}

A realidade das pequenas empresas no Brasil segundo Kassai (1997) as coloca como responsáveis por uma parcela importante da economia, principalmente ao se considerar o setor informal. Uma pesquisa realizada pelo SEBRAE (2009) mostrou que as micro e pequenas empresas representam uma boa fatia na economia nacional, em que representam 98,9 \% das empresas do país e 40,1 \% dos empregos gerados. Segundo o SEBRAE (2011), no Brasil são criados mais de 1,2 milhão de novas empresas e desse total $99 \%$ são micro empresas e empreendedores individuais, isso comprova que a sobrevivência dessas empresas é imprescindível para o crescimento da economia do país. Ainda de acordo com a pesquisa o 


\section{Informação contábil nas micro e pequenas empresas: uma pesquisa de campo na cidade de Tangará da Serra - MT \\ Riky Grachecki Vilas Boas; Márcio Íris de Morais}

período mais difícil para uma empresa são os dois primeiros anos de atividade e que as taxas de sobrevivência das mesmas estão aumentando, o dado mais recente mostra que a cada 100 empresas criadas, 73 sobrevivem aos dois primeiros anos de atividade.

Para Iudícibus e Marion, (1999) várias empresas, principalmente as pequenas, fecham suas portas ou enfrentam sérios problemas de sobrevivência. Eles relatam que empresários criticam a carga tributária, os juros altos, a falta de recursos, os encargos sociais, etc., fatores estes que, contribuem para enfraquecer a empresa. Porém, quando eles chegam a suas investigações, constatam que a "célula cancerosa" não repousa naquelas críticas, mas no erro gerencial, nas decisões tomadas sem respaldo, sem dados confiáveis. Por fim observam nesses casos, uma contabilidade desvirtuada, em decorrência de ter sido elaborada única e exclusivamente para atender as exigências fiscais.

Estas empresas vêm a cada ano que passa apresentando bons números de crescimento e aumentando a taxa de sobrevivência (SEBRAE, 2013). Segundo pesquisa realizada pelo SEBRAE (2013), nos últimos anos houve um crescimento acelerado na criação de novas empresas e optantes pelo SIMPLES Nacional. Em dezembro de 2012 havia 7,1 milhões de empresas desse porte, número $26 \%$ superior se comparado com dezembro do ano anterior. O estudo revelou que tanto a criação de novas empresas como a taxa de sobrevivência das mesmas com até dois anos de existência vem melhorando a cada ano. Silva et al (2010), afirmam que em meio a muitos motivos, o talento natural ou as vezes a perda do emprego, são fatores que estimulam a criação de uma pequena empresa, podendo observar que a falta de planejamento é algo comum nesses casos.

\subsection{Gestão empresarial}

A contabilidade, além de gerar informações, admite explicar os fenômenos patrimoniais, construir modelos de prosperidade, efetuar análises, controlar e também serve para prever e projetar exercícios seguintes, entre tantas outras funções (OLIVEIRA; MULLER; NAKAMURA, 2000). A complexidade das organizações, com seu processo de departamentalização e divisão em unidades de negócio, criaram a demanda de uma ferramenta que mensure o desempenho desses setores ou unidades (FERNANDES; KLANN; FIGUEREDO, 2011). Assim, Bordin e Gatti (2001), afirmam que as pequenas e médias empresas bem organizadas na área administrativa e operacional, necessitam de informações úteis e confiáveis como ferramenta gerencial para a tomada de decisões da administração. Para tanto irão necessitar de uma contabilidade também organizada que siga os padrões das 


\section{Informação contábil nas micro e pequenas empresas: uma pesquisa de campo na cidade de Tangará da Serra - MT \\ Riky Grachecki Vilas Boas; Márcio Íris de Morais}

normas e técnicas contábeis.

É interessante que as empresas tenham meios tecnológicos de informações como subsídio na elaboração do sistema de informação e, Padoveze (2009) conceitua tecnologia da informação como o conjunto tecnológico a disposição das empresas para concretizar seu subsistema de informação. Ele cita que esse panorama tecnológico está normalmente ligado à informática e a telecomunicação, bem como a todo o desenvolvimento cientifico do processo de transmissão de dados. O mesmo autor ainda classifica o sistema de informação como de apoio à gestão, que são segundo ele os sistemas ligados à vida econômico-financeira da empresa e as necessidades de avaliação de desempenho dos administradores internos. $\mathrm{O}$ autor complementa que esses sistemas podem ser utilizados pelas áreas administrativa e financeira da empresa, com o intuito de planejamento, controle financeiro e avaliação de desempenho dos negócios, e como exemplos desses sistemas ele cita o sistema de informação contábil, o sistema de custos, de orçamento, etc.

O sistema de informação contábil pode ser definido como o conjunto de recursos humanos e de capital dentro da organização o qual é responsável pela preparação de informações financeiras e também das informações obtidas da coleta e processamento dos dados das transações (GIL, 1999).

Para Oliveira (2000), o sistema de informação contábil traz automaticamente a noção de conjunto sendo composto por elementos, que são, basicamente, as pessoas e os equipamentos, que se inter-relacionam em busca de um objetivo comum, um dos objetivos é prover informações que satisfaçam as necessidades de seus usuários. Já Zanoteli (2001), diz que o sistema de informação contábil é um conjunto de recursos humanos, tecnológicos e organizacionais, que tem por objetivo prover informações úteis para apoiar o processo de tomada de decisão. Moscove, Simkin e Bagranoff (2002) complementam afirmando que o sistema de informação contábil se concentra em coletar, processar e fornecer informações de cunho financeiro para as partes externas à companhia (como investidores, credores e órgãos da receita) e partes internas (principalmente a administração).

Kassai (1997), diz que em diversos autores consultados, não restam duvidas sobre a importância da Contabilidade e a utilidade do trabalho do contador, contudo, vários autores ressaltam que o empreendedor tem dificuldades em compreender e dominar a lógica contábil. Para Kassai (1997), isso muitas vezes, ao invés de suprir o empreendedor com informações para o processo de tomada de decisões, transforma os relatórios financeiros preparados pelo contador em mero cumprimento de uma obrigação legal.

Independente do tamanho, enquadramento fiscal ou societário, a contabilidade é obrigatória para todas as empresas. Todavia, não deve ser feita apenas por exigência 


\section{Informação contábil nas micro e pequenas empresas: uma pesquisa de campo na cidade \\ de Tangará da Serra - MT \\ Riky Grachecki Vilas Boas; Márcio Íris de Morais}

legal, mas sim como uma ferramenta de gestão, em que as tomadas de decisões pelos diversos usuários possam se basear na real situação da entidade (VARGAS; VARELA; SCARPIN, 2011).

Oliveira, Muller e Nakamura (2000) destacam que a contabilidade não existe apenas para o cumprimento das obrigações legais. Dizem que além dessa função, ela também é importante para orientar o administrador no gerenciamento da empresa, constituindo o que é chamado por vários autores de contabilidade gerencial. Iudicibus (2007), afirma que a Contabilidade Gerencial, está voltada para a administração da empresa, procurando suprir de informações que sejam efetivas nas decisões do administrador. Segundo ele a Contabilidade Gerencial em suas aplicações se vale de outros campos do conhecimento além da Contabilidade e que todo procedimento, técnica, informações ou relatórios contábeis são feitos para que a administração utilize na tomada de decisão.

\subsection{Demonstrações Contábeis}

O Comitê de Pronunciamentos Contábeis através do CPC PME (2009) trata sobre a contabilidade para pequenas e médias empresas. Este pronunciamento técnico apresenta requisitos de contabilidade e divulgação quanto às demonstrações contábeis para fins gerais para essa classe de empresas. O pronunciamento relata que as pequenas e médias empresas não têm obrigação pública de prestação de contas e elaboram demonstrações contábeis apenas para fins gerais aos usuários externos. "As demonstrações contábeis são preparadas e apresentadas para usuários externos em geral, tendo em vista suas finalidades distintas e necessidades diversas" (CRC PR, 2011, p. 9).

Para Ponte e Oliveira (2004) órgãos reguladores da prática contábil têm expedido normas abordando sobre a divulgação das demonstrações contábeis, devido à preocupação com o fornecimento de informações contábeis que possam atender exigências de usuários externos. "As PMEs muitas vezes produzem demonstrações contábeis apenas para o uso de proprietários-administradores ou apenas para o uso de autoridades fiscais ou outras autoridades governamentais" (CPC PME, 2009, p.4).

O CPC PME (2009) define o conjunto de demonstrações contábeis que devem ser divulgadas pelas pequenas e médias empresas e que a entidade deve divulgá-las pelo menos anualmente. O conjunto completo de demonstrações inclui as seguintes demonstrações contábeis:

- Balanço patrimonial ao final do período;

- Demonstração do resultado do período de divulgação; 


\section{Informação contábil nas micro e pequenas empresas: uma pesquisa de campo na cidade \\ de Tangará da Serra - MT \\ Riky Grachecki Vilas Boas; Márcio Íris de Morais}

- Demonstração do resultado abrangente do período de divulgação;

- Demonstração das mutações do patrimônio líquido para o período de divulgação;

- Demonstração dos fluxos de caixa para o período de divulgação;

- Notas explicativas, compreendendo o resumo das políticas contábeis significativas e outras informações explanatórias.

"A contabilidade tem por finalidade principal o controle patrimonial, econômico e financeiro das entidades, função para a qual os profissionais contábeis têm condições de contribuir ao elaborarem e apresentarem as demonstrações contábeis aos seus usuários" (VARGAS; VARELA; SCARPIN, 2011, p. 2). O “objetivo das demonstrações contábeis é oferecer informação sobre a posição financeira (balanço patrimonial), o desempenho (demonstração do resultado) e fluxos de caixa da entidade, que seja útil aos usuários para a tomada de decisões econômicas" (CPC PME, 2009, p. 3).

De acordo com o CRC PR (2011), um dos objetivos das Demonstrações Contábeis é de apresentar os resultados da atuação da administração na gestão da entidade e de sua capacidade na prestação de contas quanto aos recursos que lhe foram confiados. E para aqueles usuários que desejam avaliar a atuação ou prestação de contas da administração, devem fazer com a finalidade de estar em condições de tomar decisões econômicas, como reeleger ou substituir a administração, manter ou vender seus investimentos na entidade.

\section{METODOLOGIA}

Quanto aos objetivos este estudo é descritivo, de natureza quantitativa. Segundo Gil (2002), esse tipo de pesquisa tem como principal característica descrever características de uma determinada população. Este estudo procura fazer essa descrição, da importância dada a informação contábil nas micro e pequenas empresas, e qual a percepção dos gestores em relação ao uso dessas informações. É de natureza quantitativa, pois foi necessário quantificar as informações coletadas usando meios estatísticos. Richardson (1999), define que os métodos quantitativos caracterizam-se pelo emprego da quantificação tanto nas modalidades de coleta de informações, quanto no tratamento delas por meios estatísticos, desde os mais simples aos mais complexos.

Nesse tipo de pesquisa, os fatos são observados, registrados, analisados, classificados e interpretados, sem que o pesquisador interfira neles. Isto significa que os fenômenos do mundo físico e humano são estudados, mas não manipulados pelo pesquisador (ANDRADE, 2006).

O desenho da pesquisa, bem como do questionário, foi fundamentado em pesquisa 


\section{Informação contábil nas micro e pequenas empresas: uma pesquisa de campo na cidade de Tangará da Serra - MT Riky Grachecki Vilas Boas; Márcio Íris de Morais}

bibliográfica. Para Vergara (2006, p. 48), pesquisa bibliográfica é "o estudo sistematizado desenvolvido com base em material publicado em livros, revistas, jornais, redes eletrônicas, isto é, material acessível ao público em geral" Oliveira (1999, p.119), complementa que "a pesquisa bibliográfica tem por finalidade conhecer as diferentes formas de contribuição científica que se realizaram sobre determinado assunto ou fenômeno”.

Quanto à coleta dos dados, foi feito um levantamento ou survey ${ }^{3}$. De acordo com Colauto e Beuren (2006), os dados coletados nesse tipo de pesquisa podem ser baseados numa amostra retirada da população, sempre levando em consideração que nenhuma amostra é perfeita, podendo variar o grau de erro ou viés. Gil (2002, p.70), diz o seguinte sobre pesquisas de levantamento ou survey:

“[...] se caracterizam pela interrogação direta das pessoas cujo comportamento se deseja conhecer. Basicamente, procede-se a solicitação de informações a um grupo significativo de pessoas acerca do problema estudado para em seguida, mediante análise quantitativa, obter as conclusões correspondentes aos dados coletados."

Os dados foram levantados por meio de questionários, utilizando o método de amostragem não probabilística por acessibilidade, em que os participantes foram selecionados pela facilidade de acesso aos mesmos. Segundo Gil (2011), esse tipo de amostragem não representa fundamentação matemática ou estatística, dependendo única e exclusivamente do pesquisador. $\mathrm{O}$ autor ainda define que o pesquisador seleciona os elementos a que tem acesso, considerando que de alguma forma representam o universo. A população da pesquisa foi informada pelo setor de Alvará da Prefeitura Municipal de Tangará da Serra-MT, via relatório de todas as empresas com situação ativa no município, representando um total de 3.606. A partir dessa população foi selecionada a amostra.

Na sequência, a fórmula que determinou o tamanho da amostra (GIL, 2011).

$$
n=\frac{\sigma^{2} \times p \times q \times N}{e^{2}(N-1)+\sigma^{2} \times p \times q}
$$

Onde:

$\mathrm{n}=$ Tamanho da amostra

$\sigma^{2}=$ Nível de confiança escolhido, expresso em número de desvios-padrão

$\mathrm{p}=$ Percentagem com a qual o fenômeno se verifica

$\mathrm{q}=$ Percentagem complementar

\footnotetext{
${ }^{3}$ Survey é um método de coleta de informações diretamente de pessoas a respeito de suas idéias, sentimentos, saúde, planos, crenças e de fundo social, educacional e financeiro. Disponível em: <http://www.carlosmello.unifei.edu.br/Disciplinas/Mestrado/PCM-10/SlidesMestrado/Metodologia_Pesquisa_2012-Slide_Aula_9_Mestrado.pdf $>$. 


\section{Informação contábil nas micro e pequenas empresas: uma pesquisa de campo na cidade

$\mathrm{N}=$ Tamanho da população

$\mathrm{e}^{2}=$ Erro máximo permitido

Para o cálculo foi escolhido um nível de confiança de 95,5\% que é representado por dois desvios padrão, a percentagem com a qual o fenômeno se verifica foi estimada em $20 \%$, ficando a percentagem complementar em $80 \%$ e o erro máximo permitido foi de $5 \%$. Deste modo, o cálculo ficou da seguinte forma:

$$
\begin{aligned}
& \mathrm{n}=\frac{4 \times 20 \times 80 \times 3.606}{25 \times 3.605+4 \times 20 \times 80} \\
& \mathrm{n}=\frac{23.078 .400}{96.525} \\
& \mathrm{n}=239
\end{aligned}
$$

Presumindo que o número de respondentes seja ignorado, utilizou-se como amostra 240 empresas, número encontrado conforme determinado na fórmula. A coleta de dados foi realizada no mês de Janeiro de 2014 com aplicação de questionário composto por perguntas fechadas.

Foi necessário caracterizar a população por porte de micro empresas (ME) e empresas de pequeno porte (EPP), uma vez que a amostra foi feita pelo total de empresas da cidade de Tangará da Serra-MT. Para isso foi utilizado o critério do SEBRAE (2005), que toma por base o número de empregados. Assim foi possível chegar aos resultados esperados, já que o foco da pesquisa são as micro e pequenas empresas. O tratamento dos dados e análise dos resultados foi realizado durante os meses de Março e Abril, utilizando o software Microsoft Excel para tabulação como tabelas e gráficos necessários.

\section{ANÁLISE DOS RESULTADOS}

Esta seção apresenta os resultados da pesquisa de forma descritiva e em gráficos conforme questionário aplicado. A tabulação dos dados foi realizada através de tabelas em planilha eletrônica EXCEL, apresentando-os em gráficos. 
Informação contábil nas micro e pequenas empresas: uma pesquisa de campo na cidade

de Tangará da Serra - MT

Riky Grachecki Vilas Boas; Márcio Íris de Morais

Gráfico 1 - Função desempenhada na empresa

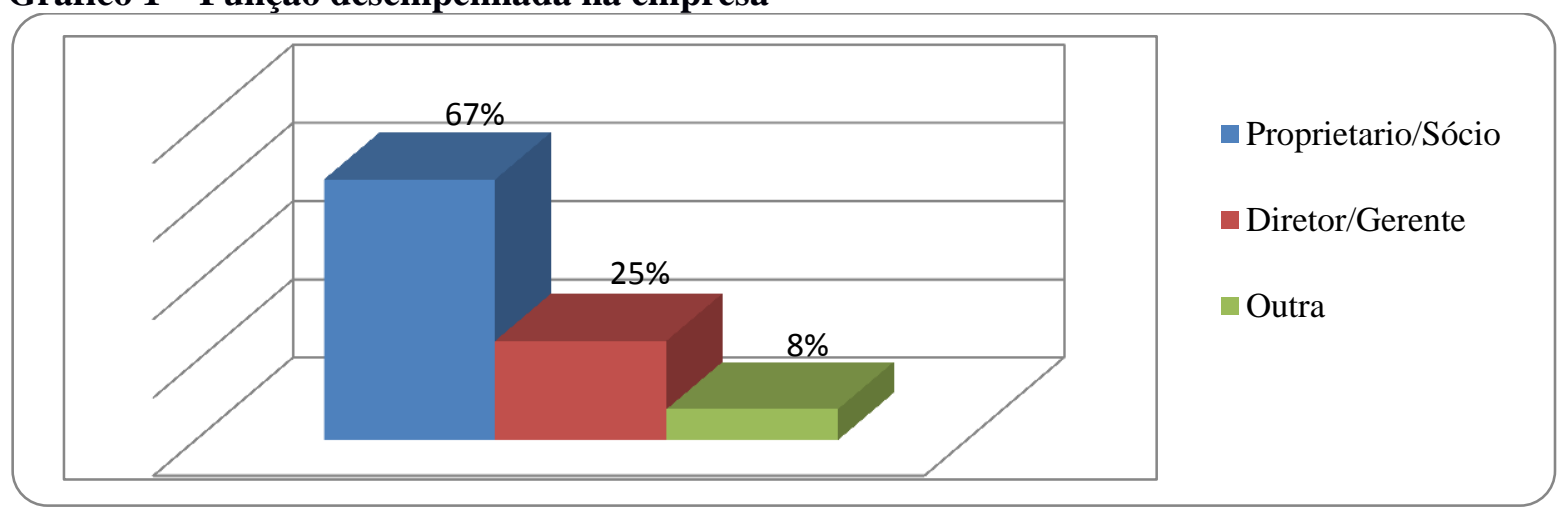

FONTE: dados da pesquisa

Conforme gráfico 1, perguntou-se quanto ao cargo ocupado pelos respondentes nas empresas pesquisadas, constata-se que a maioria, $67 \%$ são o proprietário ou sócio, uma vez que ao aplicar o questionário buscou-se localizar o responsável pela mesma, tendo a pessoa certa para as respostas, $25 \%$ foram o diretor ou gerente e $8 \%$ exercem outra função.

\section{Gráfico 2 - Porte da empresa}

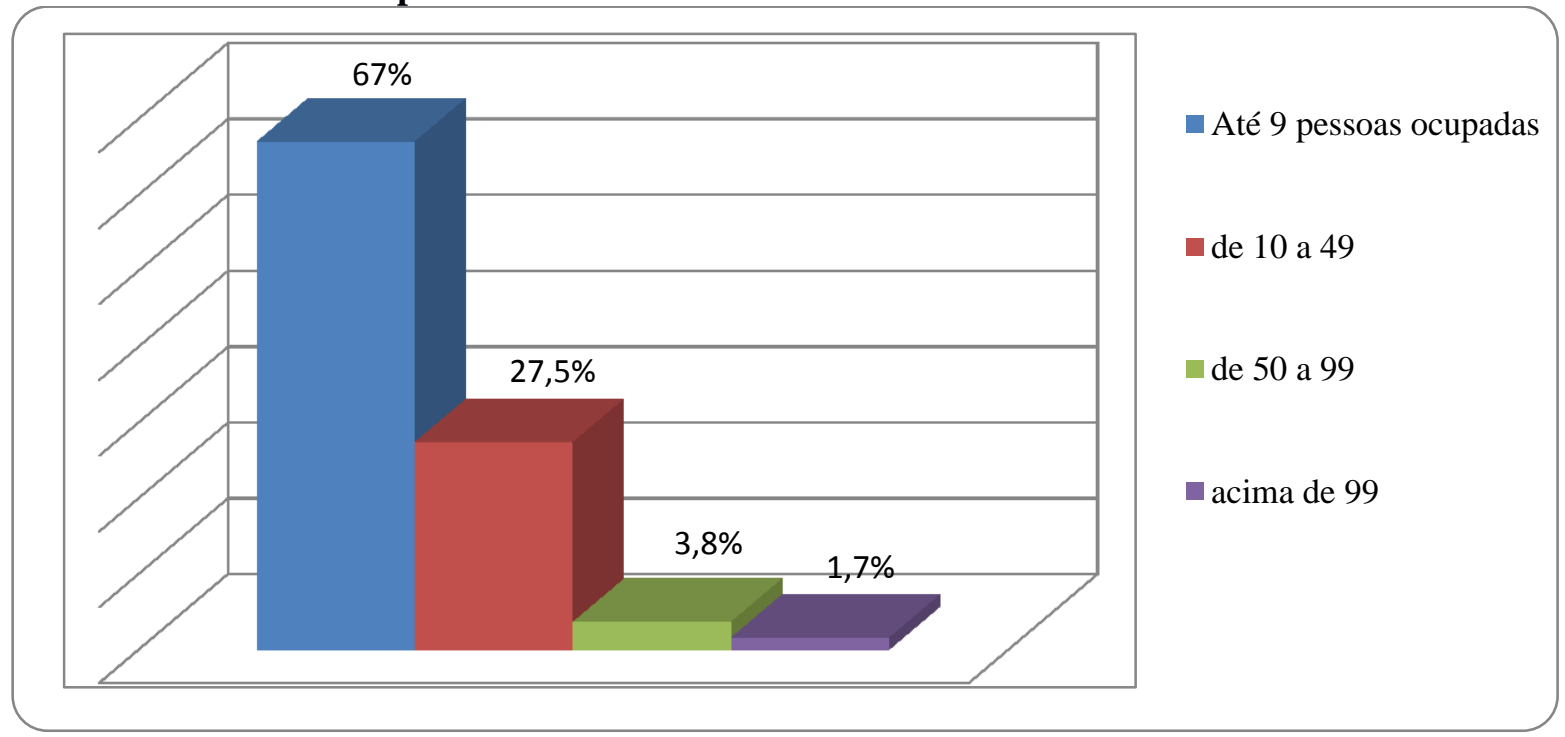

FONTE: dados da pesquisa

Para a caracterização da amostra foi utilizado o critério do SEBRAE (2005), conforme disposto no gráfico 2, que classifica as empresas por porte de acordo com o número de funcionários. Até 9 colaboradores são consideradas micro empresas, que representaram $67 \%$ da pesquisa, empresas de pequeno porte são as de 10 a 49 colaboradores com 27,5\%, de 50 a 99 são as médias empresas que resultaram em 3,8\% dos respondentes e as grandes empresas são as acima de 99 colaboradores em que obtivemos $1,7 \%$ dos respondentes. 
Informação contábil nas micro e pequenas empresas: uma pesquisa de campo na cidade

de Tangará da Serra - MT

Riky Grachecki Vilas Boas; Márcio Íris de Morais

Gráfico 3 - Atividade principal da empresa

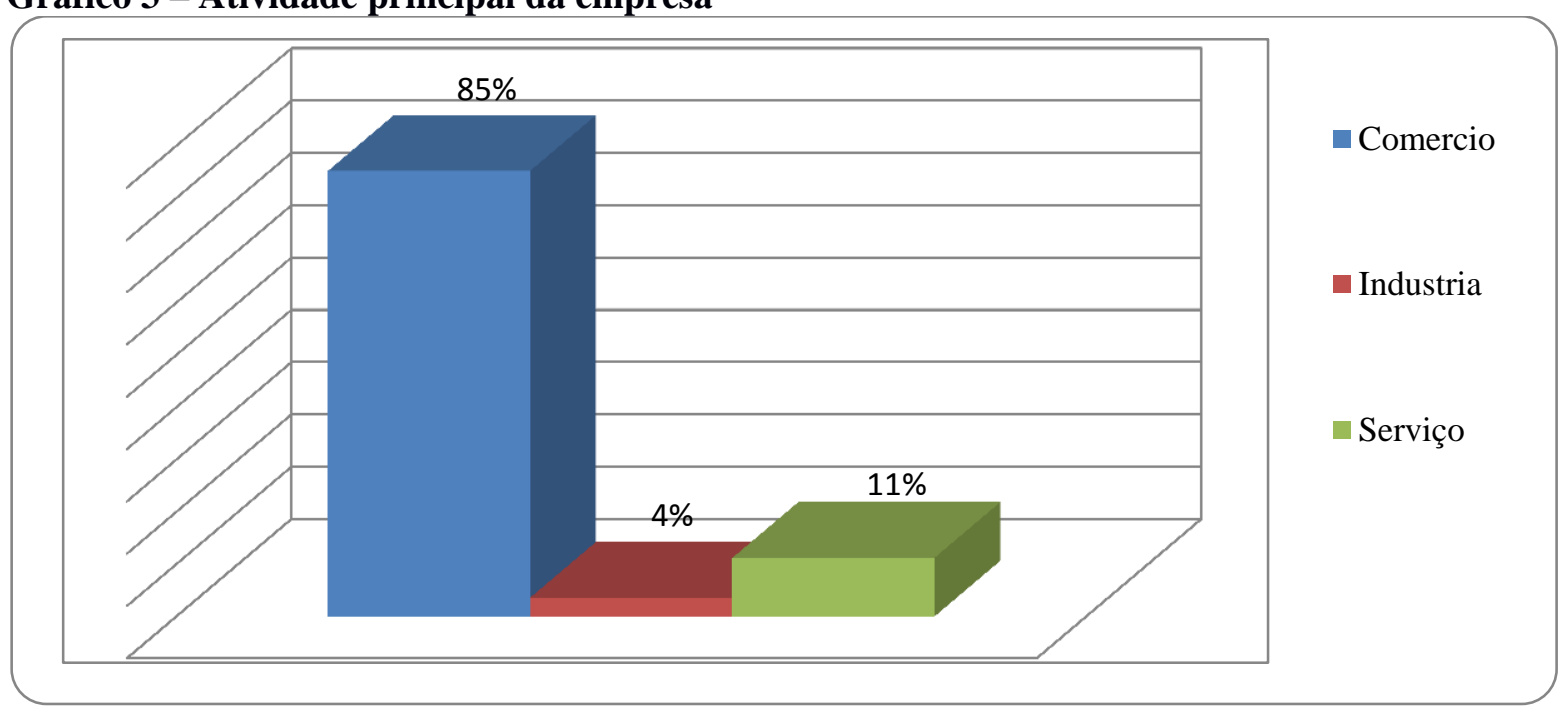

FONTE: dados da pesquisa

Ainda se tratando da caracterização das empresas foi questionada qual a principal atividade da empresa, em que os resultados demonstram no gráfico 3 que $85 \%$ dos entrevistados exercem atividade de comércio, $4 \%$ indústria e $11 \%$ serviço.

Gráfico 4 - Tempo de funcionamento da empresa

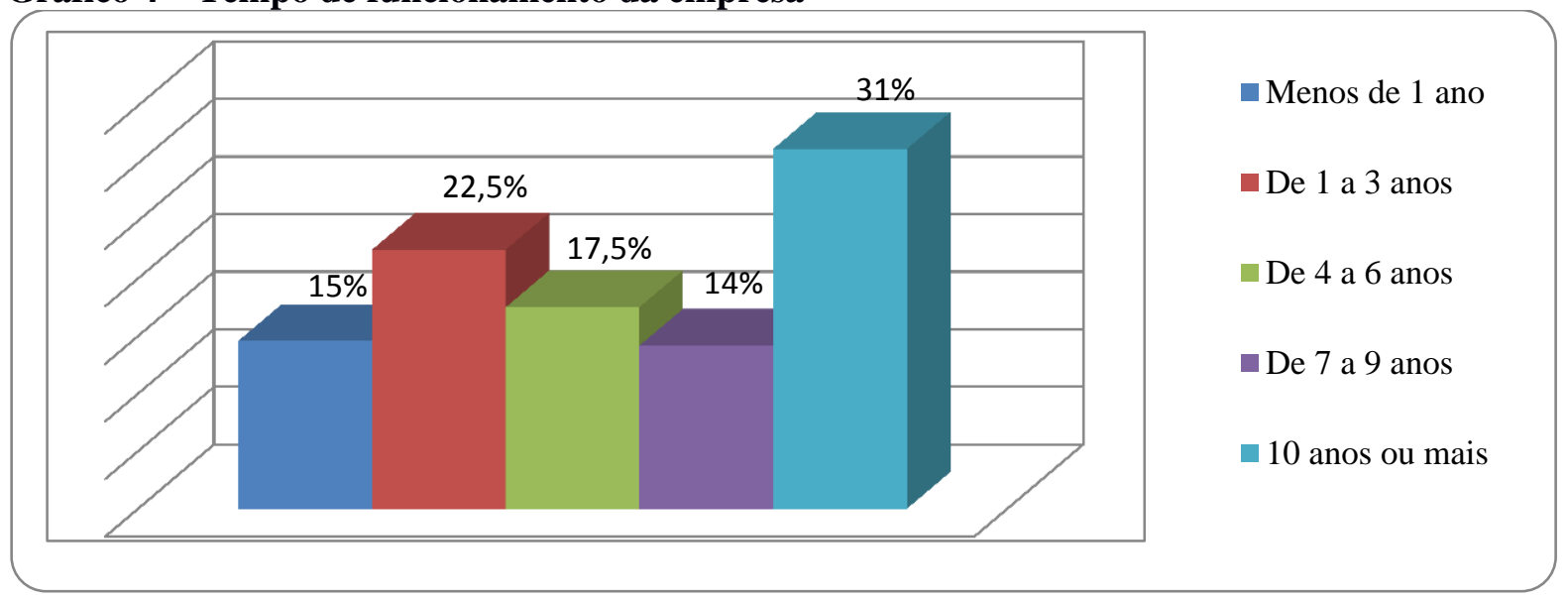

FONTE: dados da pesquisa

Chama a atenção que quando perguntado quantos anos de atuação da empresa, demonstrado acima no gráfico 4, 31\% estão com 10 anos ou mais, revelando um bom número de empresas já consolidadas no mercado. Moreira et al (2013) pesquisaram 146 micro e pequenas empresas em Teófilo Otoni-MG, desse total 51,4\% tinham 10 anos ou mais de atuação, número superior ao encontrado na cidade de Tangará da Serra-MT. Em contrapartida as empresas com menos de 1 ano e de 1 a 3 anos representaram juntas 37,5\%, enquanto em Teófilo Otoni-MG, resultaram em 25,4\%, sendo assim, em Teófilo Otoni-MG há um menor número de empresas com riscos de sobrevivência, pois o período mais difícil para 
Informação contábil nas micro e pequenas empresas: uma pesquisa de campo na cidade

de Tangará da Serra - MT

Riky Grachecki Vilas Boas; Márcio Íris de Morais

as mesmas são os dois primeiros anos de atividade (SEBRAE, 2011).

Gráfico 5 - De que forma é realizada a contabilidade

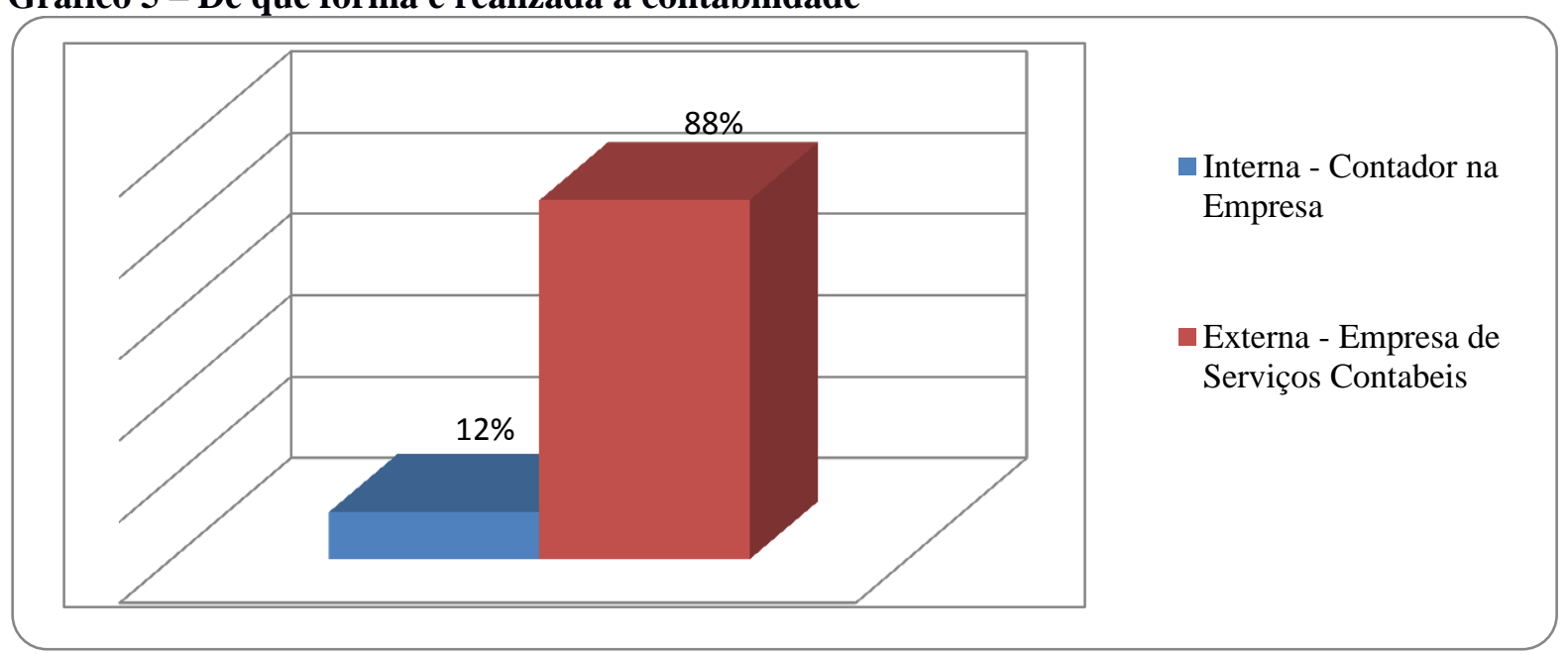

FONTE: dados da pesquisa

A maioria das empresas estudadas, conforme gráfico 5 acima, utilizam os serviços contábeis externamente, sendo que $88 \%$ contratam alguma empresa de serviços contábeis para realizar a contabilidade, e apenas $12 \%$ realizam internamente com contador na própria empresa. Isso se deve principalmente pelo fato de que o foco da pesquisa são empresas pequenas, sendo possível notar que maioria das empresas com contabilidade interna são empresas de médio ou grande porte.

Gráfico 6 - Demonstrações contábeis/relatórios que recebe do contador ou empresa de serviços contábeis

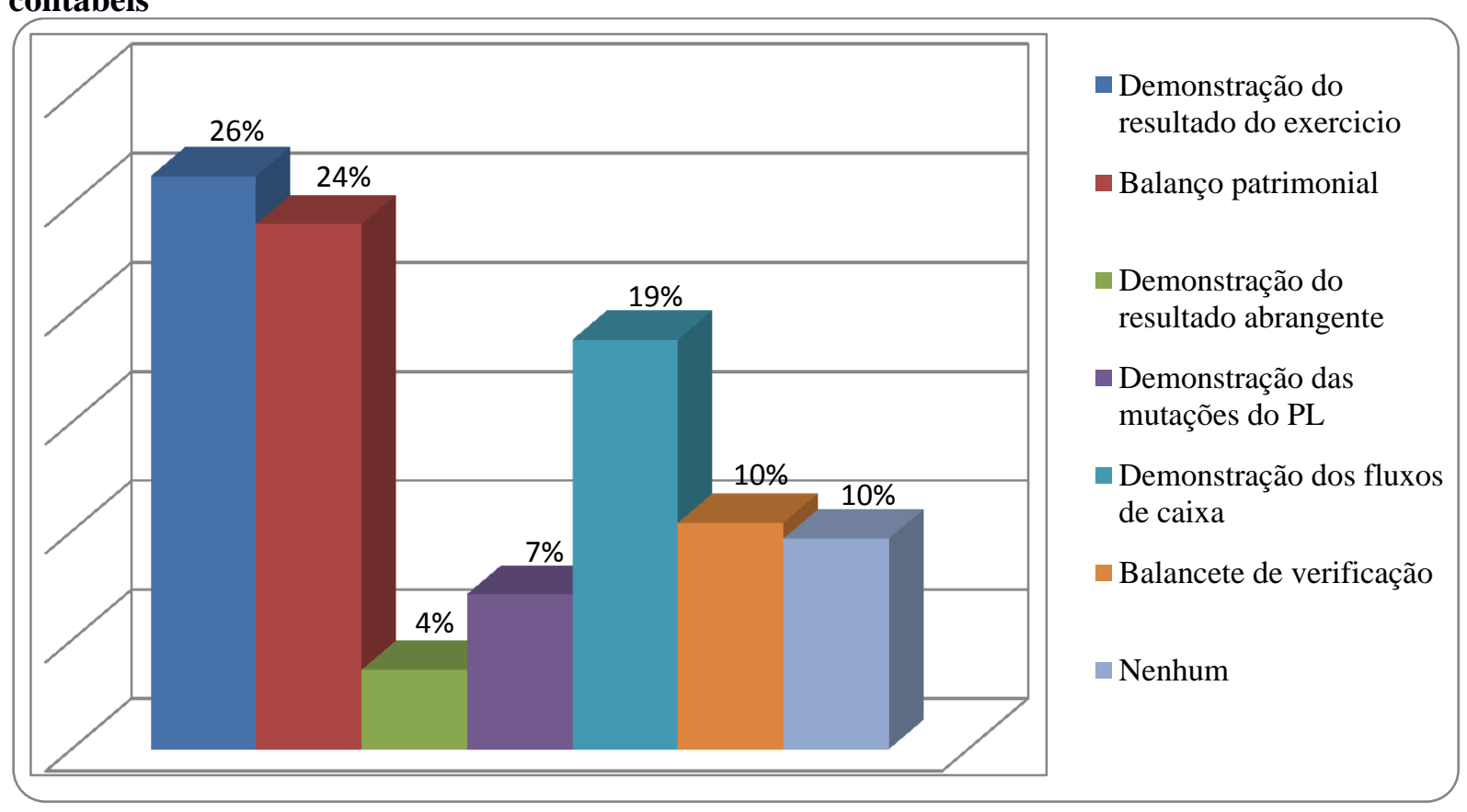

FONTE: dados da pesquisa 


\section{Informação contábil nas micro e pequenas empresas: uma pesquisa de campo na cidade de Tangará da Serra - MT \\ Riky Grachecki Vilas Boas; Márcio Íris de Morais}

Quando indagado quais demonstrações contábeis ou relatórios recebe da contabilidade, como demonstra no gráfico 6 , os dados apontaram que os que são mais disponibilizados são a demonstração do resultado do exercício com $26 \%$, o balanço patrimonial com $24 \%$ e a demonstração dos fluxos de caixa com 19\%. É importante destacar que $10 \%$ dos respondentes opinaram que não recebem nenhum relatório ou demonstração, número preocupante, mas nem tanto se comparado com o estudo de Moreira et al (2013) em Teófilo Otoni-MG com 146 micro e pequenas empresas, em que 32,9\% responderam que não recebem nenhum relatório da contabilidade, constatando assim melhores retornos da contabilidade em Tangará da Serra-MT do que em Teófilo Otoni-MG quanto a relatórios recebidos da contabilidade. O estudo em Teófilo Otoni-MG ainda revelou que apenas 8,9\% dos pesquisados recebem fluxos de caixa, balanço patrimonial e demonstração do resultado do exercício, sendo assim o resultado divergente com o resultado da presente pesquisa, já que esses relatórios são os mais recebidos em Tangará da Serra-MT. Já no estudo realizado por Silva et al (2010) em 55 empresas na região metropolitana de Recife-PE, as informações fornecidas com mais frequência são a demonstração do resultado do exercício, o balanço patrimonial e a conciliação bancária.

Gráfico 7 - Utiliza a informação contábil como apoio na gestão empresarial?

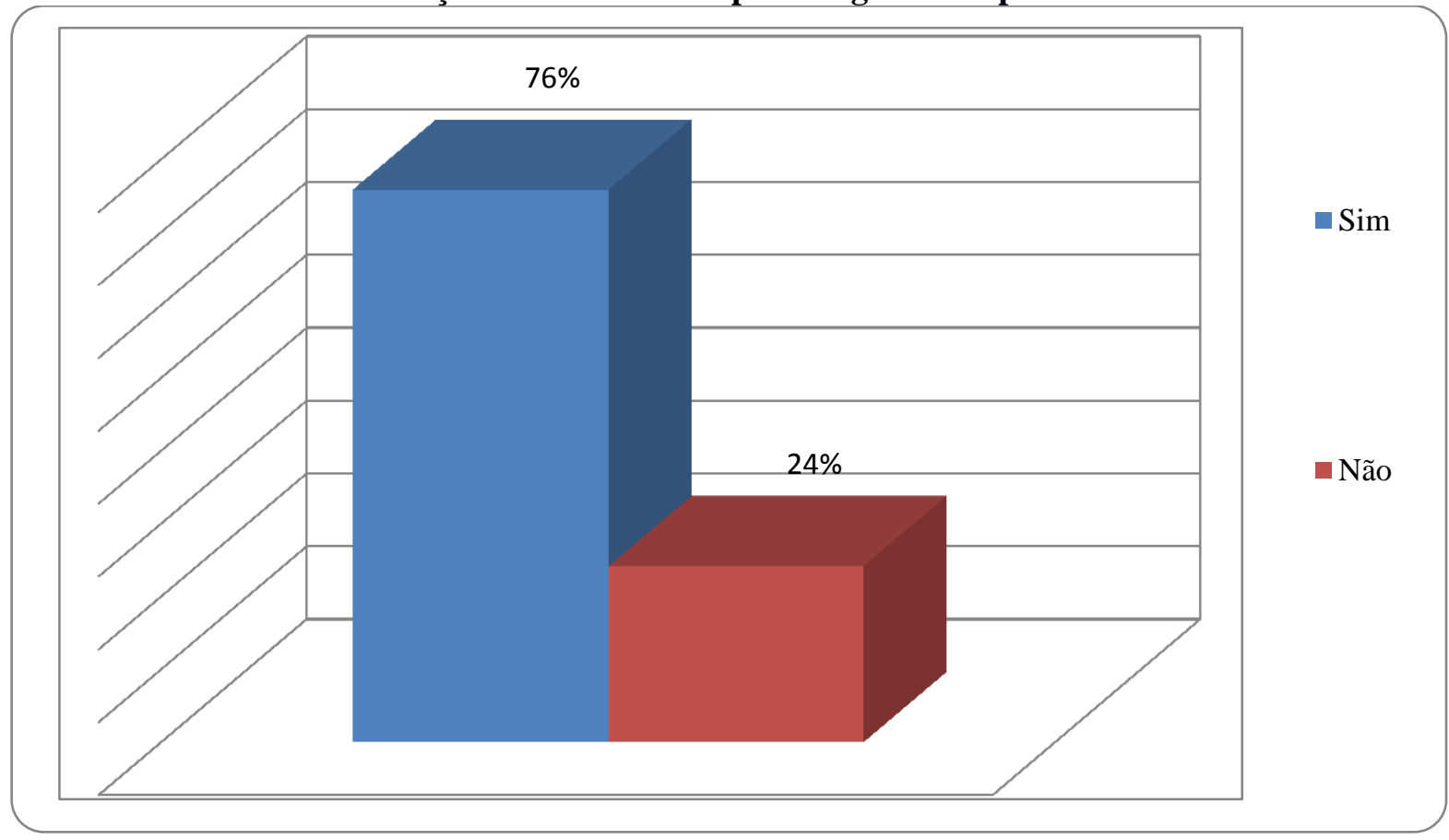

FONTE: dados da pesquisa

Como apontado no gráfico 7, a pesquisa revelou que $76 \%$ dos responsáveis pelas empresas pesquisadas utilizam a informação contábil como apoio na gestão empresarial, 
Informação contábil nas micro e pequenas empresas: uma pesquisa de campo na cidade

de Tangará da Serra - MT

Riky Grachecki Vilas Boas; Márcio Íris de Morais

enquanto $24 \%$ não utilizam.

Gráfico 8 - Se a resposta anterior foi sim, escolha a (s) alternativa (s):

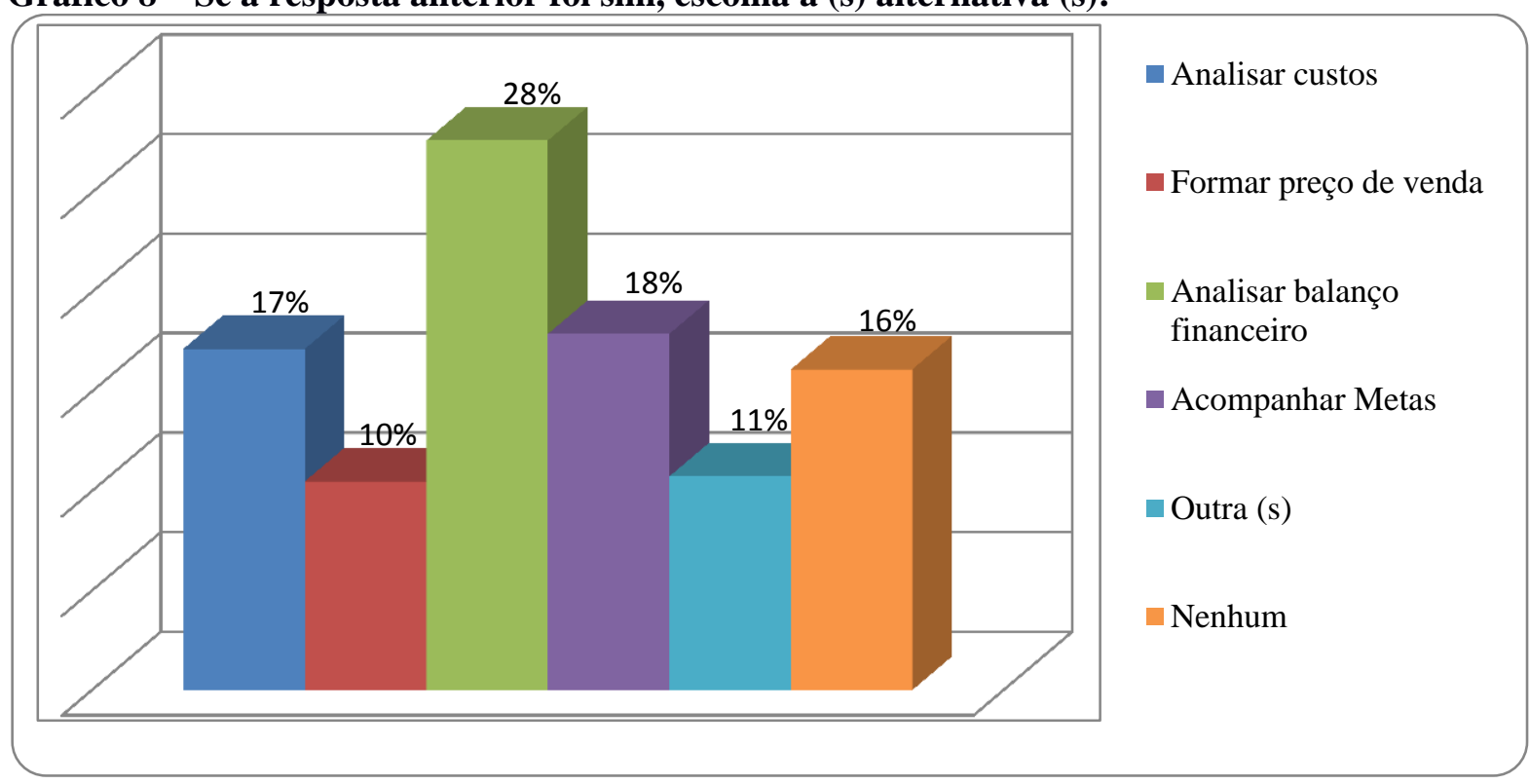

FONTE: dados da pesquisa

Como complemento a resposta da questão anterior, foi solicitado aos respondentes que utilizam a informação contábil como apoio na gestão empresarial, a indicarem se utilizam para alguma das opções sugeridas, como evidencia o gráfico 8. Assim 28\% opinaram que utilizam para analisar o balanço financeiro da empresa, 18\% para acompanhar metas, 17\% para analisar custos e $16 \%$ responderam nenhum, sendo os que não utilizam.

\section{Gráfico 9 - Periodicidade das demonstrações disponibilizadas}

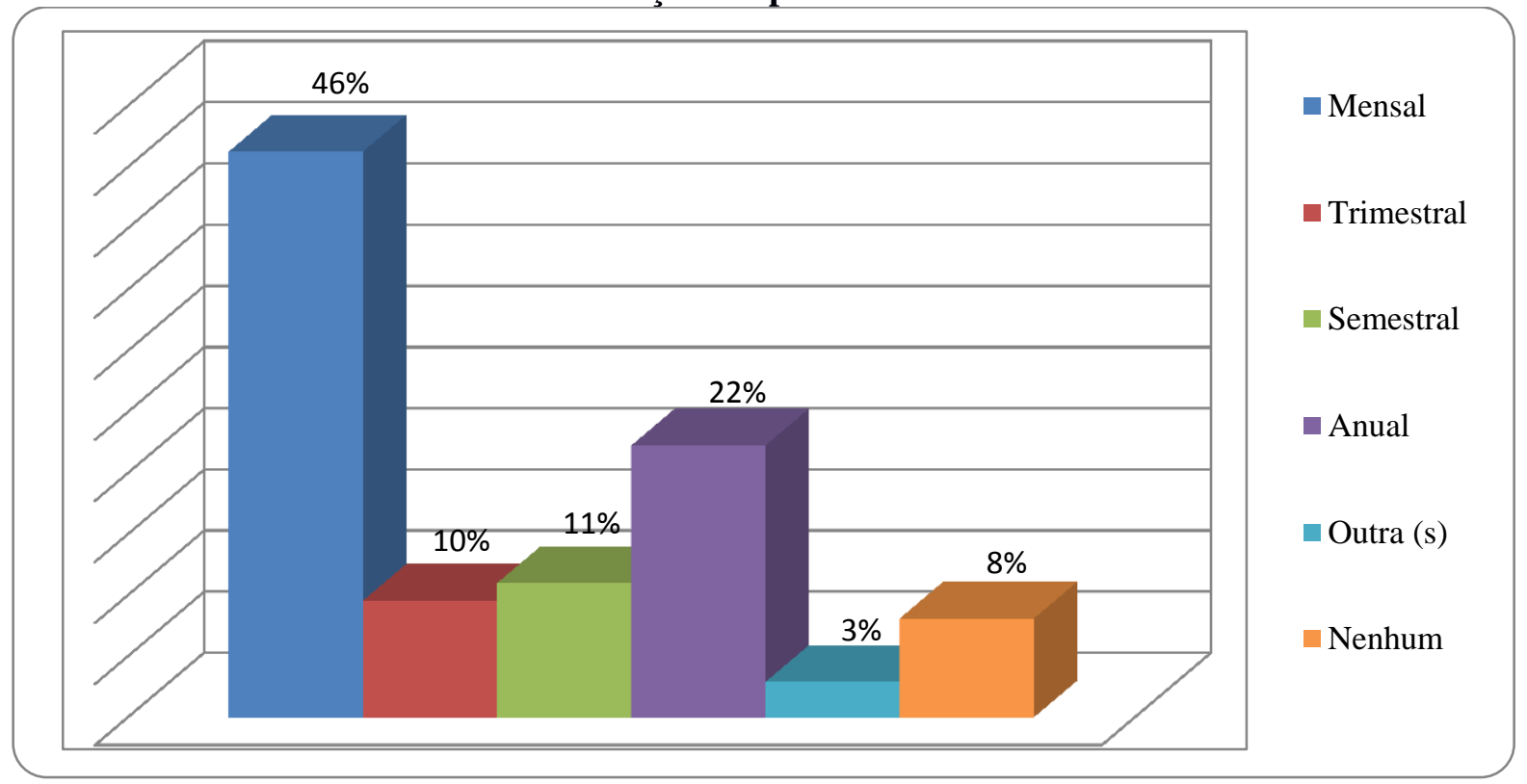

FONTE: dados da pesquisa 
Informação contábil nas micro e pequenas empresas: uma pesquisa de campo na cidade

de Tangará da Serra - MT

Riky Grachecki Vilas Boas; Márcio Íris de Morais

Quanto a periodicidade das demonstrações que são disponibilizadas pela contabilidade, o gráfico 9 exibe que $46 \%$ disseram que recebem mensalmente, $22 \%$ anualmente, $11 \%$ semestralmente, $10 \%$ trimestralmente, $3 \%$ opinaram outra (s) e $8 \%$ disseram que não recebem.

Gráfico 10 - As informações em forma de demonstrações ou relatórios recebidas da contabilidade são importantes para o suporte à gestão empresarial?

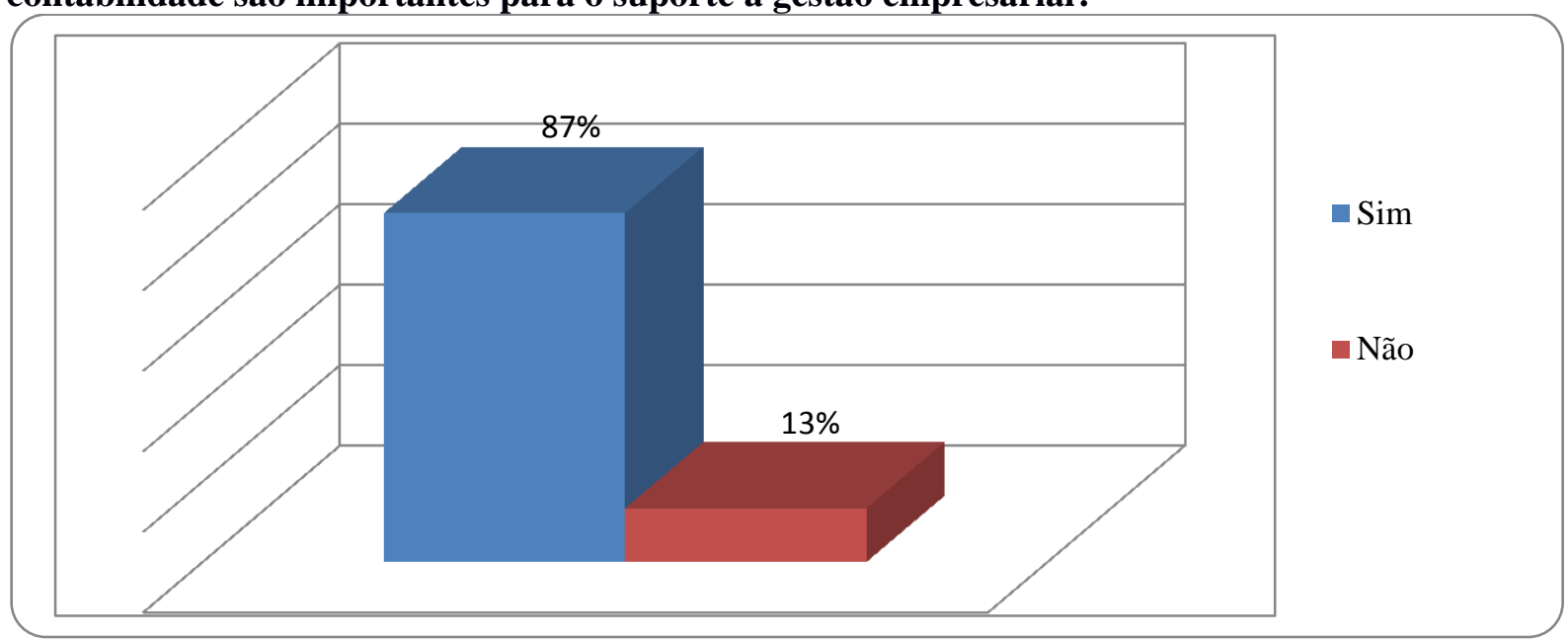

FONTE: dados da pesquisa

Em busca de avaliar a importância dada por gestores e empresários as informações recebidas da contabilidade em forma de relatórios ou demonstrações, foi questionado se eles consideram importantes essas informações para o suporte a gestão empresarial. A pesquisa comprova por meio do gráfico 10 que, $87 \%$ percebem essas informações como importantes para a gestão da empresa e 13\% opinaram não ser importante.

Gráfico 11 - Quem analisa a informação contábil em sua empresa?

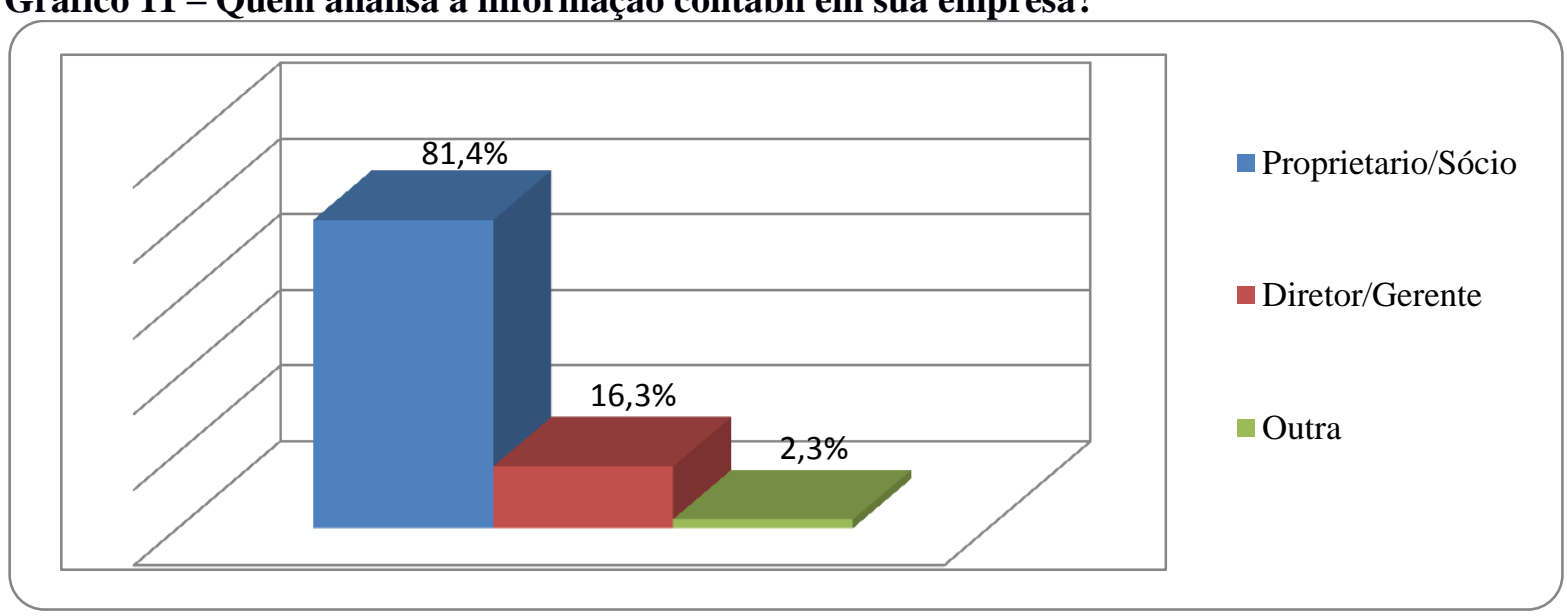

FONTE: dados da pesquisa

Os dados despontaram como no gráfico 11 acima que, em 81,4\% das empresas pesquisadas quem analisa a informação contábil é o proprietário ou o sócio, em 16,3\% o 
Informação contábil nas micro e pequenas empresas: uma pesquisa de campo na cidade de Tangará da Serra - MT

Riky Grachecki Vilas Boas; Márcio Íris de Morais

gerente ou diretor e apenas em 2,3\% pessoas que exercem outra função. Resultado esperado já que maioria das empresas pesquisadas são micro empresas e parte expressiva delas o proprietário é quem administra.

Gráfico 12 - A informação contábil analisada é confiável?

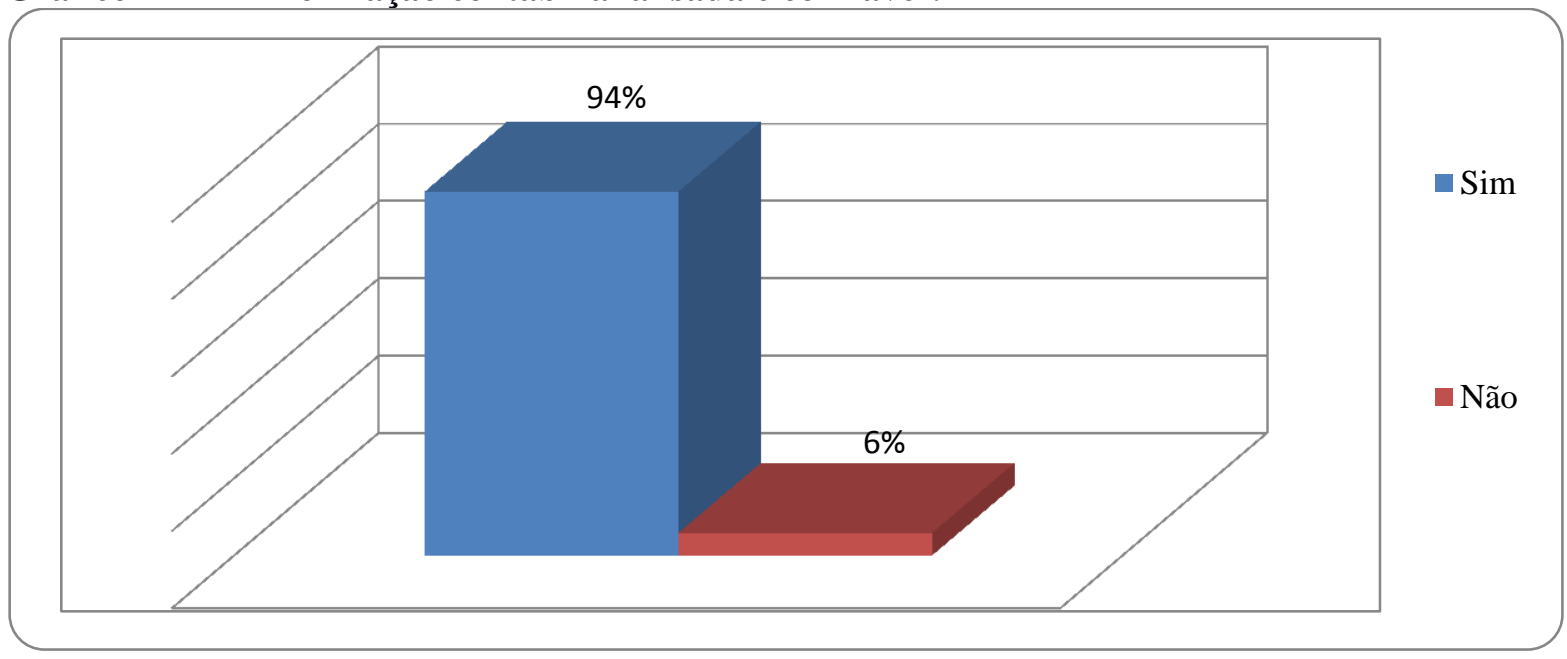

FONTE: dados da pesquisa

Após constatar quem analisa a informação contábil, foi possível verificar a confiabilidade das informações contábeis, emitidas pelos gestores e empresários, respondentes do questionário. A maioria, como expõe o gráfico 12, $94 \%$ disseram que a informação contábil que recebem da contabilidade é confiável, enquanto $6 \%$ percebem não ser confiável. Um ótimo resultado, mostrando que os contadores de Tangará da Serra-MT, estão transmitindo confiança nas informações que repassam a seus clientes e usuários. Resultado que vai de encontro ao de Recife-PE no estudo realizado por Silva et al (2010), em que foi encontrado um resultado semelhante, visto que $87,3 \%$ disseram que a informação contábil é confiável, enquanto $12,7 \%$ relataram que não é confiável.

Gráfico 13 - Possui dificuldade em utilizar a informação contábil?

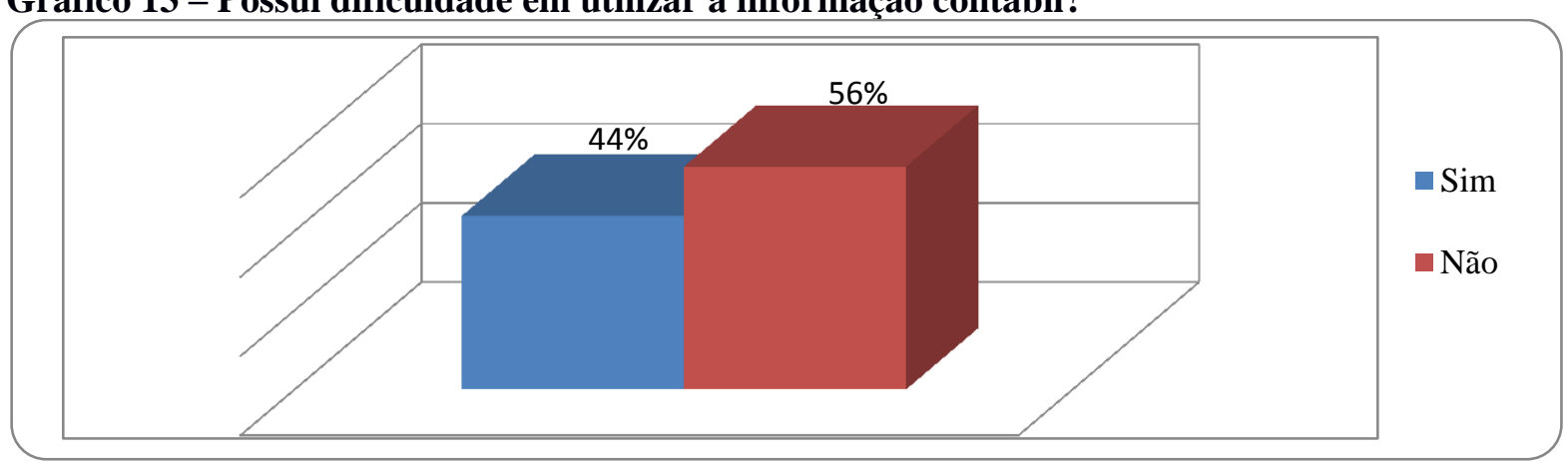

FONTE: dados da pesquisa

Em relação à dificuldade em utilizar a informação contábil, o gráfico 13 demonstra 


\section{Informação contábil nas micro e pequenas empresas: uma pesquisa de campo na cidade de Tangará da Serra - MT \\ Riky Grachecki Vilas Boas; Márcio Íris de Morais}

que, $56 \%$ disseram que não possuem tal dificuldade e $44 \%$ disseram que sim, possuem dificuldade para tal. O resultado mostra que gestores e empresários vem a cada dia se preparando mais, neste caso maior parte não possuem dificuldade, manifestando um número expressivo de pessoas capacitadas para utilizar a informação contábil com facilidade. No estudo de Silva et al (2010) em Recife-PE, 34,5\% opinaram que possuem dificuldade em utilizar a informação contábil, enquanto $65,5 \%$ opinaram que não possuem dificuldade, um número melhor que o encontrado em Tangará da Serra-MT.

Gráfico 14 - Se a resposta anterior foi sim, quais dificuldades:

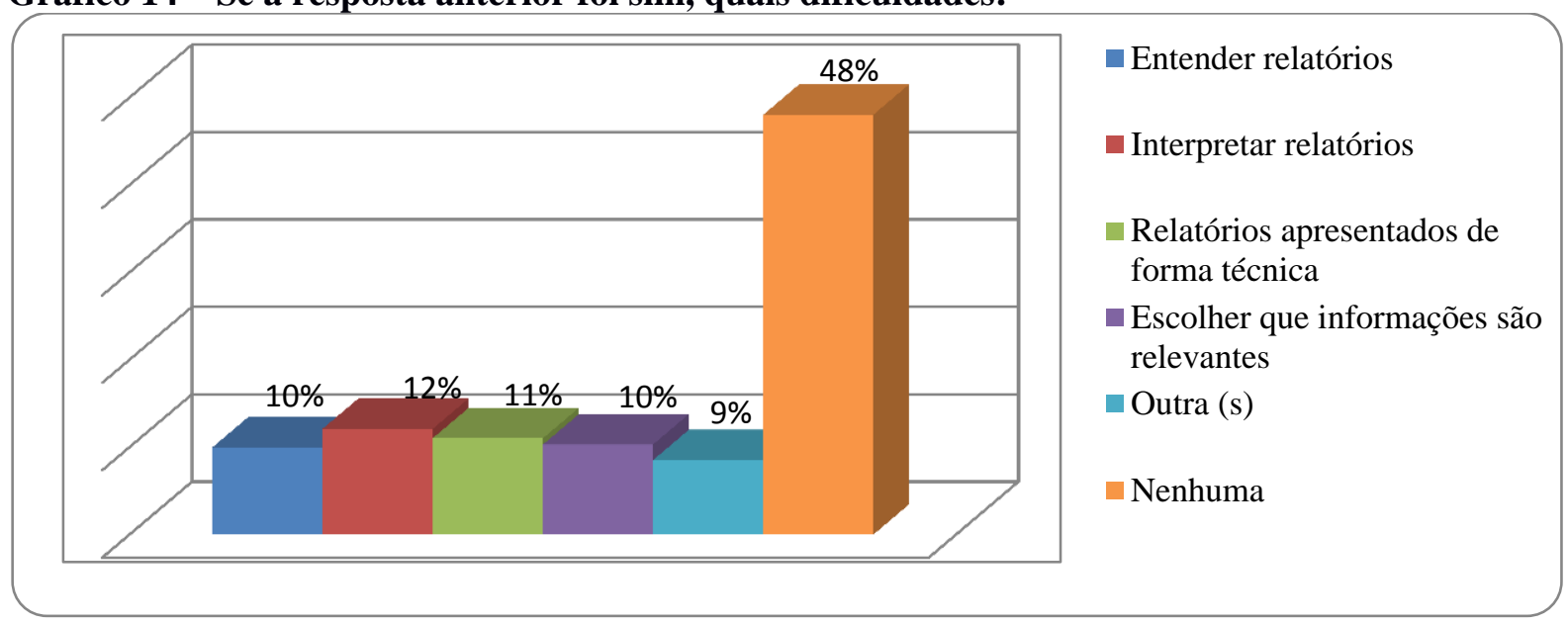

FONTE: dados da pesquisa

Por fim buscou-se verificar quais dificuldades os gestores e empresários possuem ao utilizar a informação contábil. O gráfico 14 revela que, maioria respondeu que não possuem nenhuma dificuldade, esse número é representado pelos respondentes que disseram na questão anterior não possuir dificuldade em utilizar a informação contábil. Os resultados ficaram perto um do outro, uma vez que podiam marcar mais de uma alternativa nesta questão. A maior dificuldade encontrada foi de interpretar relatórios com 12\% das respostas, $11 \%$ marcaram que os relatórios são apresentados de forma técnica, empatados com 10\% ficaram os com dificuldade em entender relatórios e escolher que informações são relevantes e 9\% disseram que possuem outras (s) dificuldades.

\section{CONSIDERAÇÕES FINAIS}

Este estudo investigou qual a percepção de gestores e empresários das micro e pequenas empresas de Tangará da Serra-MT em relação ao uso da informação contábil. Para isso, buscou-se avaliar a importância que é dada pelos mesmos a informação contábil recebida por meio de relatórios e demonstrações da contabilidade, verificando ainda sobre a 


\section{Informação contábil nas micro e pequenas empresas: uma pesquisa de campo na cidade de Tangará da Serra - MT \\ Riky Grachecki Vilas Boas; Márcio Íris de Morais}

confiabilidade das informações contábeis na opinião dos gestores e empresários.

A análise dos dados revelou que os mesmos percebem a informação contábil como importante ferramenta de suporte a gestão das empresas, e que a grande maioria utiliza os relatórios e demonstrações que recebem como apoio na gestão empresarial, grande parte disseram que utilizam para analisar o balanço financeiro da empresa, analisar custos e acompanhar metas. Por outro lado, apesar de a maioria reconhecer a importância da informação contábil, um número representativo de $24 \%$ não utiliza a informação contábil como apoio na gestão de suas empresas.

O estudo revelou que $88 \%$ das empresas realizam a contabilidade de forma externa, um número expressivo provavelmente em função de que as micro e pequenas empresas não possuem estrutura adequada e suficiente para manterem uma contabilidade interna. Os relatórios ou demonstrações que eles recebem com mais frequência de seus contadores são a demonstração do resultado do exercício, o balanço patrimonial e a demonstração dos fluxos de caixa, sendo em sua maioria em periodicidade mensal e anual.

Quanto à confiabilidade das informações contábeis, quase a totalidade opinaram que a informação contábil que recebem é confiável, sendo um passo importante para que eles possam utilizá-la como apoio na gestão empresarial, uma vez que confiam nas informações contábeis recebidas. Apesar de confiarem nas informações produzidas pela contabilidade, parcela significativa, $44 \%$ possuem dificuldade em utilizar a informação contábil, apontando dificuldades como: interpretar relatórios, relatórios apresentados de forma técnica e escolher que informações são relevantes.

Diante dos resultados, recomenda-se aos contadores e empresas de serviços contábeis que ainda não oferecem serviços de assessoria a seus clientes, que o façam como forma de poder apoiá-los na gestão empresarial, além de verificar como estão sendo apresentadas as informações em forma de relatórios e demonstrações, buscando simplificar e demonstrar de forma com que seus clientes tenham o mínimo de dificuldades. Já os gestores e empresários, podem aprimorar seus conhecimentos buscando melhor entendimento em relação à informação contábil, para assim, amenizar essas dificuldades por meio de feedback ${ }^{4}$ com seus contadores.

Quanto às limitações, houve dificuldade na coleta dos dados. Os questionários foram aplicados pessoalmente com o objetivo de alcançar o melhor resultado, e desta forma

\footnotetext{
${ }^{4}$ Feedback: palavra em inglês que no português significa retorno, resposta, crítica, análise crítica. Disponível em: < http://www.dicionarioinformal.com.br/feedback/>. 
Informação contábil nas micro e pequenas empresas: uma pesquisa de campo na cidade

de Tangará da Serra - MT

Riky Grachecki Vilas Boas; Márcio Íris de Morais

aconteceram alguns momentos difíceis. Em alguns momentos gestores e empresários se recusavam a responder os questionários, em outros solicitavam que deixássemos os questionários para serem respondidos, porém não conseguíamos obter retorno do mesmo, mas com muito empenho e persistência foi possível concluir a pesquisa de forma satisfatória.

\section{REFERÊNCIAS}

ANDRADE, Maria Margarida. Introdução à metodologia do trabalho científico. 7. ed. São Paulo: Atlas, 2006.

BORDIN, A.; GATTI, I. Regime especial de tributação para as micro, pequenas e médias empresas. Revista do Conselho Regional de Contabilidade do RS. Porto Alegre, n. 107, dez. 2001.

COLAUTO, Romualdo Douglas; BEUREN, Ilse Maria. Coleta, análise e interpretação dos dados. In: BEUREN, Ilse Maria et al. Como elaborar trabalhos monográficos em contabilidade: teoria e prática. 3. ed. São Paulo, Atlas, 2006.

\section{CONSELHO REGIONAL DE CONTABILIDADE DO PARANÁ. Demonstrações}

contábeis: aspectos práticos elaboração e apresentação conceitual de acordo com o IFRS. 2011. Disponível em:

<http://www.crcpr.org.br/new/content/download/2011_demonstracoesContabeis.pdf>. Acesso em: 21/11/2013 às 23hs:45min.

COMITÊ DE PRONUNCIAMENTOS CONTÁBEIS. Pronunciamento técnico PME: contabilidade para pequenas e médias empresas. 2009. Disponível em: < http://www.cpc.org.br/pdf/CPC_PMEeGlossario_R1.pdf >. Acesso em: 12/11/2013 às 23hs:45min.

DICIONÁRIO INFORMAL. Feedback. Disponível em:

<http://www.dicionarioinformal.com.br/feedback/>. Acesso em: 23/06/2014 às 14hs:25min.

FERNANDES, Francisco Carlos; KLANN, Roberto Carlos; FIGUEREDO, Marcelo Salmeron. A utilidade da Informação Contábil para a tomada de decisões: uma pesquisa com gestores alunos. Contabilidade Vista \& Revista, vol. 22, n. 3, 2011, p. 99-126. Disponível em: <http://www.redalyc.org/articulo.oa?id=197021392005>. Acesso em 12/10/2013 às 21hs:36min.

GIL, Antonio de Loureiro. Sistemas de Informações Contábil/Financeiros $3^{\mathrm{a}}$ ed. Atlas, 1999.

GIL, Antonio Carlos. Como elaborar projetos de pesquisa. 4. ed. São Paulo: Atlas, 2002.

GIL, Antonio Carlos. Métodos e técnicas de pesquisa social. 6. ed. São Paulo: Atlas, 2011. 
Informação contábil nas micro e pequenas empresas: uma pesquisa de campo na cidade de Tangará da Serra - MT

Riky Grachecki Vilas Boas; Márcio Íris de Morais

IUDÍCIBUS, Sérgio de. Contabilidade Gerencial; São Paulo. Atlas, 2007. $6^{\text {a Ed. }}$

IUDÍCIBUS, S.; MARION, J. Curso de contabilidade para não contadores. 2. ed. São Paulo: Atlas, 1999.

KASSAI, Silvia. As empresas de pequeno porte e a contabilidade. Caderno de Estudos FIPECAFI, v.9, n.15, p. 60-74, São Paulo, 1997. Disponível em:

<http://www.scielo.brpdfcestn15n15a04.pdf > . Acesso em: 20/11/2013 às 13hs:23min.

MELLO, Carlos. Métodos quantitativos: pesquisa, levantamento ou survey. Aula 09 da disciplina de metodologia de pesquisa na UNIFEI. Disponível em:

$<$ http://www.carlosmello.unifei.edu.br/Disciplinas/Mestrado/PCM-10/Slides-

Mestrado/Metodologia_Pesquisa_2012-Slide_Aula_9_Mestrado.pdf $>$. Acesso em:

23/06/2014 às 10hr09min.

MORAIS, M. I. Educação profissional continuada sobre IRFS para PMES: A percepção de contabilistas do Estado de Mato Grosso. 2012.115 f. (Mestrado em Ciências Contábeis) -Programa de Mestrado em Contabilidade de pós graduação em Ciências Contábeis da Universidade do Vale do Rio dos Sinos-São Leopoldo-RS. 2012. Disponível em: < http://biblioteca.asav. org.br/vinculos//00000365.pdf> Acesso em: 10 abr. 2014.

MOREIRA, Rafael de Lacerda et al. A importância da informação contábil no processo de tomada de decisão nas micro e pequenas empresas. Revista Contemporânea em Contabilidade, vol. 10, n. 19, 2013, p. 119-140. Disponível em:<http://www.redalyc.org/articulo.oa?id=76226206007>. Acesso em: 18/09/2013 às $23 \mathrm{hs}: 37 \mathrm{~min}$.

MOSCOVE, Stephen A.; SIMKIM, Mark G.; BAGRANOFF, Nancy A. Sistemas de informações contábeis. São Paulo: Atlas, 2002.

OLIVEIRA, Antonio Gonçalves de; MULLER, Aderbal Nicolas; NAKAMURA, Wilson Toshiro. A utilização das informações geradas pelo sistema de informação contábil como subsídio aos processos administrativos nas pequenas empresas. Revista FAE, vol. 3, n. 3, p. 1-12. Curitiba, 2000. Disponível em:

<http://www.unifae.br/publicacoes/pdf/revista_da_fae/fae_v3_n3/a_utilizacao_das_informaço es.pdf>. Acesso em 12/10/2013 às 17hs:50min.

OLIVEIRA, Humberto Rosa. Modelagem do Processo de Compra e de Formação de Preços no Varejo: um estudo de caso em uma rede de lojas de tintas. 2000. 170f. Dissertação(Mestrado em Administração) Centro de Pós-Graduação e Pesquisas em Administração, Universidade Federal de Minas Gerais, Belo Horizonte, 2000.

OLIVEIRA, Silvio Luiz de. Tratado de metodologia científica. 2.ed. São Paulo: Pioneira, 1999.

PADOVEZE, Clovis Luiz. Sistemas de Informações Contábeis. São Paulo: Atlas, 2009.

PONTE, Vera Maria Rodrigues; OLIVEIRA, Marcelle Colares. A prática da evidenciação 
Informação contábil nas micro e pequenas empresas: uma pesquisa de campo na cidade

de Tangará da Serra - MT

Riky Grachecki Vilas Boas; Márcio Íris de Morais

de informações avançadas e não obrigatórias nas demonstrações contábeis das empresas brasileiras. Revista Contabilidade \& Finanças, vol. 15, n. 36, Universidade de São Paulo, 2004, p. 7-20. Disponível em: http://www.redalyc.org/articulo.oa?id=257119538001. Acesso em 21/11/13 às 00hs38min.

PORTON, Rosimere Alves de Bona. LONGARAY,André Andrade. Relevância do uso das informações contábeis nos processos decisionais. Revista Angrad, vol. 7, n. 4, 2006, p. 89110. Disponível em: http://www.fecap.br/extensao/artigoteca/Art_011.pdf. Acesso em 06/10/13 às $10 \mathrm{hs} 38 \mathrm{~min}$.

RICHARDSON, Roberto Jarry. Pesquisa social: métodos e técnicas. 3. ed. São Paulo: Atlas, 1999.

SEBRAE. Serviço Brasileiro de Apoio às Micros e Pequenas Empresas. Boletim estatístico de micro e pequenas empresas. Observatório SEBRAE, 2005. Disponível em:<http://www.dce.sebrae.com.brbtebte.nsf03DE0485DB219CDE0325701B004CBD01\$Fie NT000A8E66.pdf>. Acesso em: 06/10/2013 às 16hs:38min.

SEBRAE. Serviço Brasileiro de Apoio as Micro e Pequenas Empresas. Ambiente empresarial das micro e pequenas empresas gaúchas: os pequenos negócios mostram a sua força na economia. Porto Alegre: SEBRAE-RS, 2009.

$<$ http://www.mercopar.com.br/download.asp?arquivoCaminho=/files/arq_ptg_6_98.pdf\&arqu ivoNome $=$ Ambiente $\% 20$ Empresarial $\% 20$ das $\% 20$ MPEs $\% 20 \% 20$ Serra $\% 20 \mathrm{Ga} \%$ FAcha.pdf $>$. Acesso em: 06/10/2013 às 17hs:45min.

SEBRAE. Serviço Brasileiro de Apoio às Micro e Pequenas Empresas. Sobrevivência das Empresas no Brasil. Unidade de Gestão Estratégica, 2013. Disponível em:<http://bis.sebrae.com.br/OpacRepositorioCentral/paginas/downContador.zhtml?uid=937 72f4f62b0716c573d3a9ed5a6a3aa>. Acesso em: 06/10/2013 às 14hs:16min.

SEBRAE. Serviço Brasileiro de Apoio às Micro e Pequenas Empresas. Taxas de Sobrevivência das Empresas no Brasil. Unidade de Gestão Estratégica, 2011. Disponível em:<http://bis.sebrae.com.br/GestorRepositorio/ARQUIVOS_CHRONUS/bds/bds.nsf/45465 B1C66A6772D832579300051816C/\$File/NT00046582.pdf>. Acesso em: 06/10/2013 às 14hs:16min.

SILVA, Daniel José Cardoso et al. Para que Serve a Informação contábil nas Micro e Pequenas Empresas? Revista Contemporânea em Contabilidade, vol. 7, n. 13, 2010, p. 89-106. Disponível em:<http://www.redalyc.org/articulo.oa?id=76220594005>. Acesso em: 12/09/2013 às 00hs:12min.

STROEHER, Angela Maria; FREITAS, Henrique. O uso das informações contábeis na tomada de decisão em pequenas empresas. Revista de Administração Eletrônica, 2008. Disponível em:〈http://www.rausp.usp.br/Revista_eletronica/v1n1/artigos/v1n1a7.pdf >. Acesso em: 18/09/2013 às 23hs:54min.

VARGAS, Auzenir José de; VARELA, Patrícia Siqueira; SCARPIN, Jorge Eduardo. Convergência para os padrões internacionais de contabilidade em pequenas e médias empresas: percepção de gestores quanto à qualidade da informação contábil. 2011. 
Informação contábil nas micro e pequenas empresas: uma pesquisa de campo na cidade de Tangará da Serra - MT

Riky Grachecki Vilas Boas; Márcio Íris de Morais

Disponível em: 〈http://www.ead.fea.usp.brsemead14semeadresultadotrabalhosPDF246.pdf>. Acesso em: 21/11/2013 às 00hs:25min.

VERGARA, Sylvia C. Projetos e relatórios de pesquisa em administração. São Paulo: Atlas, 2006.

ZANOTELI, Eduardo José. Avaliação de Sistemas Integrados de Gestão: um estudo de caso múltiplo. 2001.262 f. Dissertação (Mestrado em Administração) Centro de Pós Graduação e Pesquisas em Administração, Universidade Federal de Minas Gerais, Belo Horizonte, 2001. 


\section{APÊNDICE A - CARTA DE APRESENTAÇÃO}

Prezados (as) Empresários (as) e Gestores (as),

Esta é uma pesquisa de Graduação da UNEMAT (Universidade do Estado de Mato Grosso) campus de Tangará da Serra, curso de Ciências Contábeis, a fim de investigar a percepção de gestores e empresários das micro e pequenas empresas de Tangará da Serra MT em relação ao uso da informação contábil.

A sua participação é fundamental para o avanço desta pesquisa, contribuindo para o tema e para empresários e gestores no mercado de trabalho.

Saiba que tem o direito de não responder a alguma pergunta, qualquer que seja o motivo. Lembramos que não existem respostas certas ou erradas, o que importa é sua opinião sincera. Caso não responda ou não opine, peço que sinalize a alternativa correspondente para que possa ter certeza de que não se esqueceu de responder a alguma pergunta.

Lembramos que nenhum dado será divulgado individualmente. Todas as informações serão tabuladas e agrupadas para análise.

Muito obrigado pela sua participação.

Riky Grachecki Vilas Boas

Graduando
Márcio Iris de Morais

Coordenador da pesquisa 
Informação contábil nas micro e pequenas empresas: uma pesquisa de campo na cidade de Tangará da Serra - MT

Riky Grachecki Vilas Boas; Márcio Íris de Morais

\section{APÊNDICE B: INSTRUMENTO COLETA DE DADOS}

\section{INFORMAÇÃO CONTÁBIL NAS MICRO E PEQUENAS EMPRESAS: UMA PESQUISA DE CAMPO NA CIDADE DE TANGARÁ DA SERRA - MT}

O objetivo da pesquisa é investigar a percepção de gestores e empresários das micro e pequenas empresas de Tangará da Serra - MT em relação ao uso da informação contábil. Para tanto, foi selecionada uma amostra de 240 empresas do total de 3.600 existentes com cadastros de Alvará ativos no município. Esclarecemos que não há necessidade de identificação do respondente, pois o questionário não se destina a uma avaliação individual. Todas as informações serão tratadas de forma confidencial. Agradecemos sua preciosa colaboração.

Marque com X a opção em que se enquadra.

1) Qual função desempenha na empresa?

( ) Proprietário/Sócio

( ) Diretor/Gerente

( ) Outra

2) Qual o número de colaboradores em sua empresa?
( ) Até 9 pessoas ocupadas
( ) de 50 a 99
( ) de 10 a 49
( ) acima de 99

3) Qual atividade principal a empresa exerce?
( ) Comércio
( ) Indústria
( ) Serviço

4) Há quantos anos a empresa está em funcionamento?
( ) Menos de 1 ano
( ) De 7 a 9 anos
( ) De 1 a 3 anos
( ) 10 anos ou mais
( ) De 4 a 6 anos

5) A contabilidade de sua empresa é realizada de forma:

( ) Interna - contador na empresa

( ) Externa - empresa de serviços contábeis

6) Quais demonstrações contábeis ou relatórios recebe do contador ou empresa de serviços contábeis? (Pode marcar mais de uma alternativa).

( ) Demonstração do resultado do exercício

( ) Balanço patrimonial

( ) Demonstração do resultado abrangente

( ) Demonstração das mutações do patrimônio líquido

( ) Demonstração dos Fluxos de Caixa

( ) Balancete de verificação 
Informação contábil nas micro e pequenas empresas: uma pesquisa de campo na cidade de Tangará da Serra - MT

Riky Grachecki Vilas Boas; Márcio Íris de Morais

( ) Nenhum

7) O gestor ou empresário utiliza a informação contábil como apoio na gestão empresarial?

( ) $\mathrm{Sim}$

( ) Não

8) Se a resposta anterior foi sim, escolha a (s) alternativa (s):
( ) Analisar custos
( ) Formar preço de venda
( ) Analisar balanço financeiro
( ) Acompanhar metas
( ) Outra (s)
( ) Nenhum

9) Qual a periodicidade das demonstrações disponibilizadas? (Pode marcar mais de uma alternativa).
( ) Mensal
( ) Trimestral
( ) Semestral
( ) Anual
( ) Outra (s)
( ) Nenhum

10) As informações em forma de demonstrações e relatórios recebidas da contabilidade são importantes para o suporte à gestão empresarial?
( ) $\operatorname{Sim}$
( ) Não

11) Quem analisa a informação contábil em sua empresa?
( ) Proprietário/Sócio
( ) Diretor/Gerente
( ) Outro

12) A informação contábil analisada é confiável?
( ) $\mathrm{Sim}$
( ) Não

13) Possui dificuldade em utilizar a informação contábil?
( ) $\operatorname{Sim}$
( ) Não

14) Se a resposta anterior foi sim, quais dificuldades:
( ) Entender relatórios
( ) Interpretar relatórios
( ) Relatórios apresentados de forma técnica
( ) Escolher que informações são relevantes
( ) Outra (s)
( ) Nenhuma 